\title{
RECENT ADVANCES IN THE TREATMENT OF PRESSURE SORES
}

\author{
By J. E. G. Shand, B.Sc., M.B., Ch.B., F.R.C.S. and Elizabeth McClemont, \\ M.B., Ch.B., D.C.H., R.C.P.S.(Glasgow) \\ Spinal Paralysis Unit, Edenhall Hospital, Musselburgh, Scotland
}

\begin{abstract}
The problem of decubitus ulceration is a common one in para- and tetraplegic patients. It is a problem which involves these patients spending long periods in hospital. In 1977 almost 50 per cent of the patients re-admitted to our Unit had skin problems. During 1977 the average time spent in our Unit with skin problems of all degrees, was almost 3 months.

Over the past few years several new products have become available for cleansing and healing these sores which, it seems, may reduce the time required in preparation for surgery or in achieving healing.

We discuss the application of these products and the results of their use in our hands.
\end{abstract}

Key words: Pressure sores; Debrisan; Corethium.

\section{Introduction}

THE problem of decubitus ulceration is a common one in hospital patients and in patients cared for in the community. Barbenel and others (1977) reported an incidence of almost 9 per cent in hospital patients and in community nursed patients in the Glasgow area and suggested, on the basis of a check survey of hospital cases, that this might be an underestimate by some 2-3 per cent.

The presence or acquisition of a decubitus ulcer often considerably delays the discharge of patients from hospital and always involves nursing staff in considerably more work.

In their study of the incidence of pressure sores in Denmark Petersen and Bittmann (I97I) found a prevalence of $43 \cdot$ I per I00,000 population and using this figure, the Glasgow group estimated that the annual cost to the Health Service of pressure sores at 1973 costs, would be roughly $£ 60$ million. In light of their own survey, Barbenel et al. (1977) now see this as a very conservative estimate.

Over the past few years the demand on the facilities of our Unit for the active treatment and rehabilitation of new cases of both traumatic and nontraumatic spinal paralysis has steadily increased. With bed occupancy consistently at Ioo per cent, we have been concerned to find ways of relieving the rate of readmission to the Unit, in order to provide a service for urgent new referrals. Table I shows the Unit statistics for 1977, and that the commonest cause for readmission was that of skin problems. The mean time spent in the Unit with skin breakdown for all patients, whether requiring surgery or not, was 3 months; the range being 7 days to I year. Whilst believing that prevention of skin problems by education is the optimum goal, we nevertheless accept that skin problems will occur. Our aims with these cases have, therefore, been to find ways of reducing treatment time, or even treating on an out-patient basis. This latter aim has recently become more tenable since many of our patients have been supplied with Simpson-Edinburgh airbeds in their homes, and can therefore be more easily nursed (McClement et al. 1978). 
PAPERS READ AT THE ANNUAL SCIENTIFIC MEETING, I 978

TABLE I

\begin{tabular}{lrlr}
\hline \multicolumn{1}{c}{ I977 Spinal unit statistics } & \multicolumn{2}{c}{ Cause of readmission } \\
Total admissions & I23 & Skin problems & 33 \\
New patients & 46 & Social & I9 \\
Readmission & 77 & Urological & I2 \\
& & G.I. & I \\
& & Vascular & I \\
& & Further rehabilitation/review & I4 \\
& & Fracture femur & 2 \\
\hline
\end{tabular}

\section{Materials and Results}

The cleansing of sloughy wounds for surgery is a notoriously slow process; the large number of products available for topical application merely serves to illustrate the difficulty of the problem.

Until recently, we have used Eusol (or Milton) solutions with ribbon gauze to soften and deslough wounds. Often other substances such as Aserbine, hydrogen peroxide, sugar, red lotion and even paw-paw fruit have been used when slough has proved resistant to initial treatment with Eusol. Having desloughed the sore, granulation tissue is encouraged by dressing with hypertonic saline, acraflavine and tullegras.

Using these methods, the average time to prepare 20 patients with $3 \mathrm{I}$ sores for surgery in the year up to August 1977, was 32 days. The sites of these sores are shown in Table II.

Two new products, Debrisan (Dextranomer) and Corethium, have recently been introduced at the Edenhall Unit in an attempt to speed the cleansing and healing of decubitus ulcers.

Debrisan (Dextranomer) is a high molecular weight dextran polymer related to similar polymers used in column chromatography. It is primarily a cleansing agent and is supplied in a fine bead form (bead diameter $0 \cdot 1-0.3 \mathrm{~mm}$ ). Beads are applied to moist wound surfaces, two or more times daily according to the amount of wound exudate. The beads, initially white, turn to a grey/yellow colour as they absorb tissue fluid; they will absorb up to four times their own weight of fluid when saturated and are easily removed from the wound surface by irrigation with sterile normal saline.

Early experimental and clinical studies from Sweden (Jacobsson et al., I976; Jacobsson et al., I976; Falk \& Tollerz, I977) show that the beads not only absorb fluid but because of their porous molecular structure, allow substances with a

\section{TABLE II}

\begin{tabular}{cr}
\hline Sites of pressure sores requiring surgery $1976-1977$ \\
\hline Ischial & II \\
Trochanteric & I2 \\
Sacral & 5 \\
Knee & I \\
Ankle & 2 \\
Total & 3I \\
\hline
\end{tabular}


molecular weight of less than 5000 to enter their interstices, while larger molecules and bacteria are drawn into the capillary spaces between the beads. Analysis of the gel removed from wounds after application of Debrisan, shows a high concentration of fibrin/fibrinogen degradation products (FDP) and it is thought that this removal prevents crusting and may explain in part the beneficial effect of Debrisan. Gel analysis has also drawn a high concentration of inflammatory mediators such as prostaglandins and this correlates with the lesser degree of inflammatory reaction found histologically and clinically in Debrisan treated ulcers compared with controls. The beads also absorb foul-smelling amines and should therefore reduce smell from severely infected wounds.

In-vitro experiments (Juhlin, I974) have drawn a high percentage absorption of bacteria and fungi into the Debrisan gel but as yet no satisfactory clinical data is available on the ability of Debrisan to remove bacteria from wounds (we are presently investigating this aspect of activity in our Unit).

Since September 1977 we have operated on 32 decubitus ulcers (the site of these ulcers is shown in Table III). Of these, I9 have been prepared in whole or part by using Debrisan in the desloughing of their wounds. The mean time taken to prepare all sores for surgery in this group was 25 days and for these in which Debrisan was used (which were in general larger and contained more moist slough) the mean preparation time was $2 \mathrm{I}$ days.

\section{TABLE III}

\begin{tabular}{|c|c|}
\hline \multicolumn{2}{|c|}{ Sites of pressure sores requiring surgery I.9.77-I.7.78 } \\
\hline Ischial & 12 \\
\hline Trochanteric & I4 \\
\hline Sacral & 4 \\
\hline Ankle & 2 \\
\hline Total & 32 \\
\hline
\end{tabular}

The following two cases serve to illustrate the beneficial effects of Debrisan.

Case No. I. A 27-year-old paraplegic was admitted with two ischial pressure sores which had been present for 2 years. Application of Debrisan to both areas led to a dramatic cleansing and reduction in size of both areas, which were ready for surgery 2 weeks from the day of admission (Figs IA and IB).

Case No. 2. A I7-year-old paraplegic youth was admitted with a right ischial pressure sore. This had occurred in the site of previous sores and had been present for 3 months. The sore was foul-smelling, filled with necrotic slough and extended down to the underlying ischial bone. Two weeks previously surgical opinion had been that this would require a rotation flap to close the extensive area adequately.

$\mathrm{He}$ was admitted to the Unit and the ulcer was treated with daily Debrisan. On the fourth day from admission, all slough had disappeared and the cavity appeared clean and healthy. Dressings continued with hypertonic saline only whilst awaiting surgery and a dramatic reduction in size of the cavity occurred, permitting straight excision and closure of the lesion (Figs $2 \mathrm{~A}$ and $2 \mathrm{~B}$ ).

The second new product which has been used in our Unit over the past 2 years is a heterograft porcine skin preparation which is used predominantly as a healing dressing (Kaisary, I977; Rundle et al., 1976) but also occasionally for its 
PAPERS READ AT THE ANNUAL SCIENTIFIC MEETING, I 978
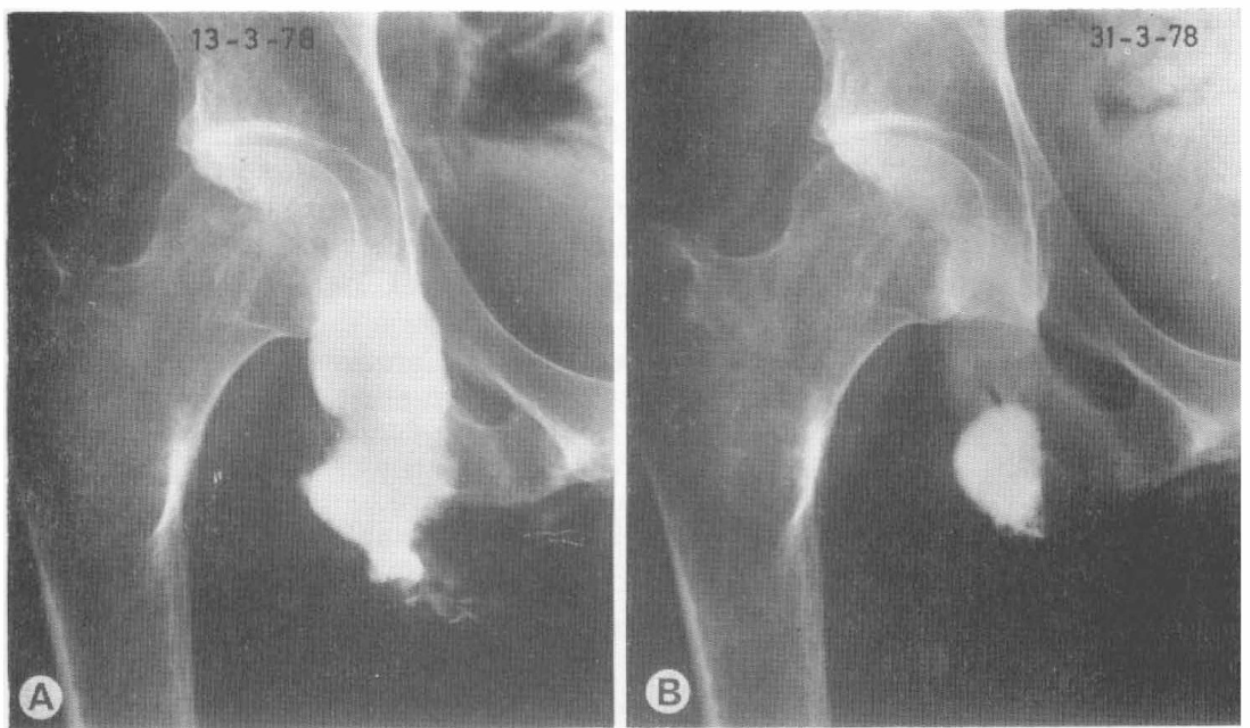

FIG. IA

Sinogram showing initial extent of ischial sore.

FIG. IB

Reduction in size after treatment with Debrisan.
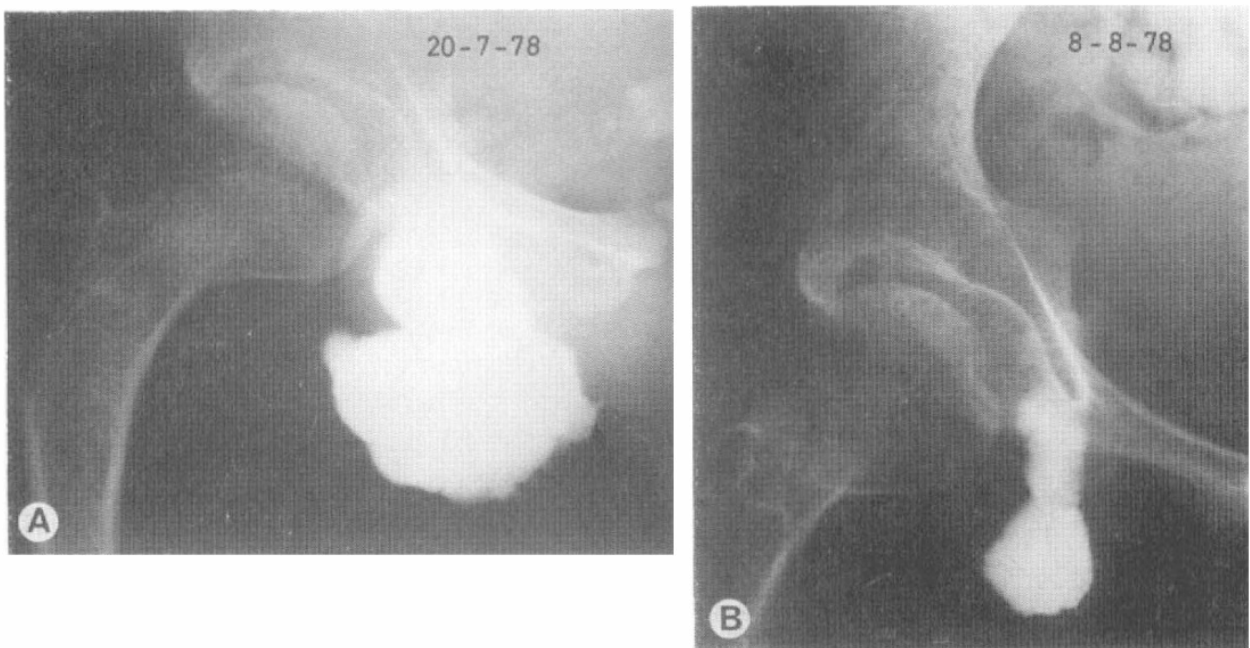

FIG. 2A

Area of cavity at start of treatment.

FIG. 2B

Ischial sore ready for simple surgical closure.

cleansing capacity. The material used in this Unit is obtained in a sterile commercial preparation-Corethium 2 Lyophilised Porcine Skin (Dermis).

During an initial period of trial, many superficial pressure sores were treated 
with Corethium 2 and the success achieved encouraged the use of the substance in major pressure sores.

The sores selected for treatment were either cleansed by other methods or had only a thin layer of slough. No sores with a thick, moist layer of separating slough or with dry eschar, were treated by this method. All sores treated with Corethium responded in the same way. There was stimulation of growth of granulation tissue; stimulation of peripheral epithelial growth and effective control of infection (inasmuch as no wound being treated with Corethium became grossly infected during treatment).

The following case report shows how effective Corethium can be:

Case Report. A 36-year-old paraplegic male was admitted with major pressure sores in the lumbar and sacral areas (Fig. $3 \mathrm{~A})$. After excision of the necrotic slough and cleansing of the extensive sacral sore, Corethium was applied to the sacral defect and also lightly packed into the undermined region of the ulcer. Stimulation of epithelial growth was noted from an early stage and with no other form of treatment, complete healing of the sacral sore was obtained (Fig. $3 \mathrm{~B}$ ). This area has remained unbroken since this treatment was completed 12 months ago.

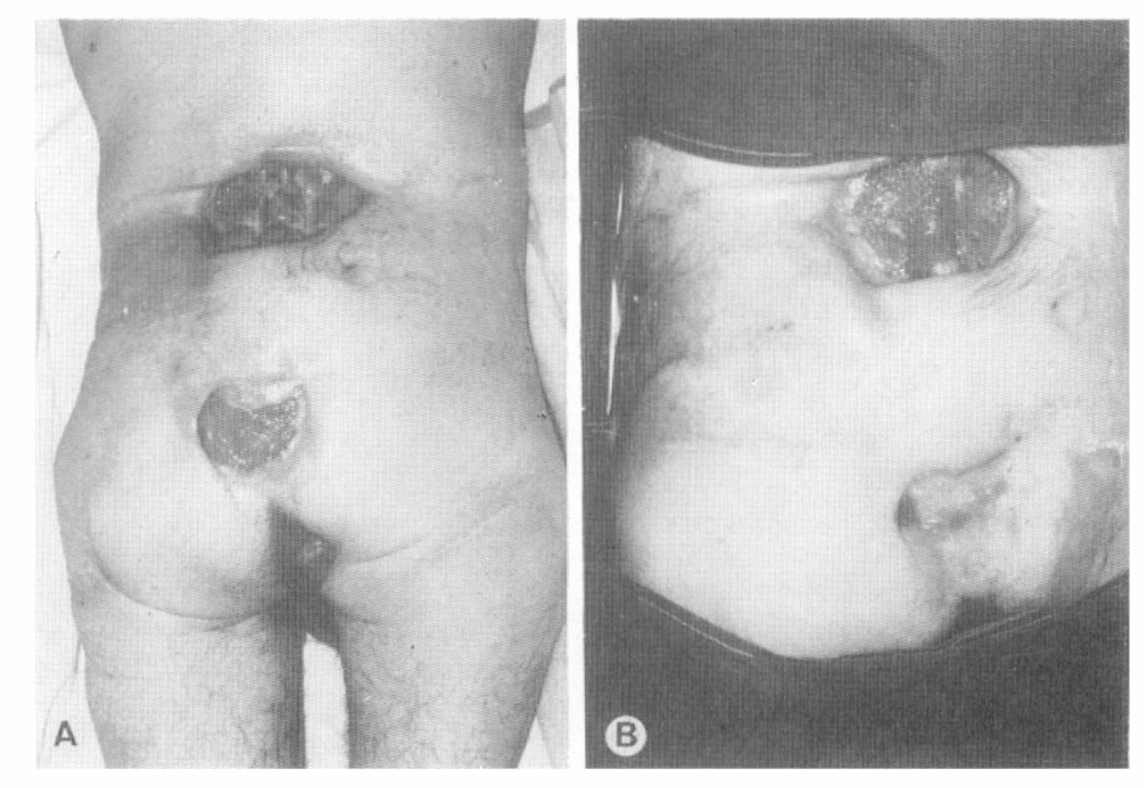

FIG. 3A

Cleansed sacral sore showing initial peripheral response to Corethium application.

FIG. 3B

Sacral area now soundly healed.

\section{Discussion}

Debrisan and Corethium are by no means used exclusively in the Edenhall Spinal Unit as dressings for decubitus ulcers; indeed it is fundamental to the success of the cleansing agent, Debrisan, that it is used where ulcers are moist and sloughing and that other softening agents, such as Eusol, are used when conditions are not favourable. 
The expense of the cleansing agent, Debrisan, has led to initial wariness about its cost effectiveness. We have found, on the contrary, a positive financial benefit in its use. Shortening the time taken to deslough ulcers, reduces the total length of stay in hospital and dressings can often be reduced from four times daily to twice or even once daily, saving both on nursing time and dressing packs. The effective stimulation of granulation tissue by Debrisan when slough has been removed, decreases the size of pressure cavities and may thus decrease the extent of surgery required to obtain satisfactory skin cover.

Positive advantages apparent with Corethium are that dressings are required less frequently and dressing technique is simple. We consider that granulations form more quickly and the quality of healing is good, reducing the need for skin grafting in the smaller sores and allowing earlier definitive treatment of larger sores. In particular the quality of skin forming over lesions treated with Corethium alone has been impressive and despite such areas being in the usual sites over bony prominences, secondary breakdown has been rare. In some instances it is possible for patients to attend on an out-patient basis with sores which would previously have led to hospitalisation and for others to be taught the dressing technique themselves.

\section{Conclusion}

The cleansing of decubitus ulcers has long been a tedious and lengthy process. Recently two new products have been developed and their selective use can appreciably decrease the time taken to heal or cleanse sores. The cost-effectiveness of both preparations is apparent.

\section{RÉSUMÉ}

Le problème d'ulcération d'escarre et commun chez les malades para et tétraplégiques. C'est un problème qui entraîne ces malades à faire des longs sejours à l'hopital. En 1977 presque $50 \%$ des malades réadmis dans notre pavillon avaient des problèmes de peau. Pendant 1977, dans notre unité le temps consacré en moyenne aux problèmes de peau à tous les stades d'évolution était presque de 3 mois. Au cours des récontres dernières années plusieurs nouveaux produits sont devenus disponibles pour nettoyer et cicatricer ces plaies; ceux-ci, semble-t-il, peuvent réduire le temps requis à la préparation pour la chirurgerie ou en vue de parvenir à cicatricer. Nous discutons de l'application de ces produits et les résultats de leur utilisation dans nos mains.

\section{ZUSAMMENFASSUNG}

Das Problem von der Dekubitalgeschwüre ist häufig unter tetraplegien Kranken. Die Folge dieses Problem ist, dass die Kranken eine lange Zeit im Krankenhaus verbringen müssen. Im Jahre I 977 fast 50\% Kranken war in unserer Station die durchschnittliche Zeit von fast drei Monate mit Hautproblemen verbracht. In dan letzten Jahren simd mehrere Produkte vorhanden um die Geschwüre zu säubern und zuheilen. Diese Produkte können die Zeit für die Verbereitung die Chururgie oder die Heilüng kürzen.

\section{REFERENCES}

Barbenel, J. C., Jordan, M. M. \& Nicol, S. M. (I977). Incidence of pressure sores in the Greater Glasgow Health Board Area. Lancet, ii, 548-550.

Falk, J. \& Tollerz, G. (I977). Tissue responses to Debrisan. Clinical Therapeutics, I, 3, I85-I9I.

$17 / 4-B$ 
Jacobsson, S., Jonsson, L., Rank, F. \& Rothman, U. (1976). Studies on healing of debrisan-treated wounds. Scandinavian fournal of Plastic Reconstructive Surgery, Io, 97-IOI.

Jacobsson, S., Rothman, U., Arturson, G., Ganrot, K., Haegar, K. \& Juhlin, I. (I976). A new principle for the cleansing of infected wounds. Scandinavian fournal of Plastic and Reconstructive Surgery, 10, 65-72.

Juhlin, I. (1974). Bacteriology. Sven Kir, 31, 2-4.

KAISARY, A. V. (1977). A temporary biological skin dressing in the treatment of varicose ulcers and skin defects. Post-Graduate Medical fournal, 53, 672-673.

McClemont, E., Simpson, D. C., McCubbin, K. J., Dick, T. D., Buchan, A. C. \& HARrIs, P. (1978). The Simpson-Edinburgh Low Pressure Air Bed. Int. F. Paraplegia, I6, I $54-159$.

Petersen, N. C. \& Bittman, S. (I97I). The Epidemiology of Pressure Sores. Scandinavian Fournal of Plastic and Reconstructive Surgery, 62-66.

Rundle, J. S. H., CAMERon, S. H. \& RuCKLEY, C. V. (1976). New porcine dermis dressing for varicose and traumatic leg ulcers. British Medical fournal, Vol. II, 2 I6. 